\title{
Executive salary stickiness, institutional investors and innovation investment -- Based on the empirical data of listed companies
}

\author{
Ding $\operatorname{xin}^{1}$ \\ ${ }^{1}$ Scool of Economics and Management, Beijing Jiaotong University, Beijing, China
}

\begin{abstract}
This paper takes China's A-share listed companies from 2015 to 2019 as the research object, and empirically tests the impact of executive compensation stickiness on enterprise innovation investment. It is found that executive compensation stickiness is positively correlated with the innovation investment of corporate and it is more significant in private enterprises. In addition, Institutional investors participate in corporate governance to play a positive governance effect, and strengthen the positive correlation between the stickiness of executive compensation and corporate innovation investment.
\end{abstract}

\section{1 introduction}

Innovation has the characteristics of high input cost, long return cycle, high risk coefficient, etc. The manager's tendency to avoid risks beforehand is likely to lead to insufficient $\mathrm{R} \& \mathrm{D}$ investment of enterprises. The theoretical analysis of Manso ${ }^{[1]}$ pointed out that the traditional performance-based compensation incentive mechanism is easy to induce executives to avoid risk, which will eventually adversely affect the level of enterprise innovation. However, many studies have pointed out that China's executive compensation has obvious sticky characteristics. The increase in executive compensation when company performance rises is greater than the decrease in executive compensation when company performance declines, that is, the changes in executive compensation and corporate performance appear obvious asymmetry ${ }^{[2]}$. The stickiness of executive salaries shows that the company prefers to reward the merits and not punish the inferior, and will be more tolerant of executives' investment failures, thereby enhancing the adventurous spirit of the executives ${ }^{[3]}$. Therefore, executive salary stickiness can be used as an incentive mechanism that combines tolerance for shortterm decision-making failures of executives with rewards for long-term success, encourages executives to actively carry out R\&D activities, and enhances the level of corporate innovation investment ${ }^{[4]}$.

As an important external governance mechanism, institutional investor shareholding has an important impact on the level of corporate innovation ${ }^{[5]}$. Institutional investors have strong motives and expertise to participate in internal governance, thereby alleviating information asymmetry, reducing agency conflicts, achieving the goal of improving corporate governance, and playing an active role in supervision and governance. Therefore, this paper will further discuss the impact of institutional investors' participation in corporate governance on the relationship between executive compensation stickiness and corporate innovation investment.

The research of this paper is mainly reflected in the following aspects: First, will the stickiness of executive compensation increase corporate innovation investment? Secondly, do institutional investors play a moderating role in the mechanism in which the stickiness of executive compensation affects corporate innovation investment?

\section{Theoretical analysis and research hypothesis}

The stickiness of executive compensation refers to the fact that performance compensation presents certain convex characteristics. From the perspective of its formation method and characteristics, it can not only cater to the personal utility of the executives and protect the manager's market position, but also make the executives fail in investment. Timely avoiding or reducing "penalties" will greatly increase the risk compensation effect of executive compensation, thereby enhancing the risk-bearing capacity of executives. Therefore, the "light penalty" feature of executive salary stickiness prevents the management from having to bear the salary loss caused by investment failure. The executive salary stickiness enhances the risk-taking spirit of the executives, which in turn stimulates the executives' innovative investment decisions and promotes corporate innovation development ${ }^{[6]}$.

Institutional investors have played a pivotal role in the capital market. The hypothesis of effective supervision believes that institutional investors have natural advantages in collecting, integrating and processing various information as both principals and agents, and their governance effects can improve the corporate 
governance structure. Especially when participating in corporate governance can bring huge benefits, institutional investors will effectively supervise and check the behavior of executives, prompting executives to invest in research and development activities that can bring longterm benefits to the company, thereby enhancing the value of the company ${ }^{[3]}$. Based on the above analysis, this paper proposes the following research hypotheses:

Hypothesis 1: Executive salary stickiness is positively correlated with corporate innovation investment.

Hypothesis 2: Institutional investors' shareholding strengthens the positive correlation between the stickiness of executive compensation and innovation investment.

\section{Research design}

\subsection{Sample selection and data sources}

This paper uses all A-share listed companies in China from 2015 to 2019 as the initial sample, uses the executive compensation and company performance data from 2011 to 2019 to calculate the stickiness of executive compensation, and screens the original data as follows: (1) exclude financial categories and ST company samples; (2) remove samples with missing data; (3) to calculate the stickiness of executive compensation, remove samples with positive or negative corporate performance growth during the rolling five-year period. Finally, 8420 sample data observations were obtained. The data involved in the study are all from CSMAR database.

\subsection{Variable selection}

This paper measures the company's innovation investment by the ratio of the company's R\&D expenditure and the current year's operating income.

In the study of $\mathrm{Xu}$ Yue et al. ${ }^{[3]}$ and $\mathrm{Bu}$ Danlu ${ }^{[7]}$, using the company's salary data and performance data to quantify the indicator of executive salary stickiness:

$$
\begin{gathered}
N X_{i, t}=\sum_{u=i}\left(\frac{\text { pay }_{t}-\text { pay }_{t-1}}{\text { aay }_{t-1}} / \frac{N I_{t}-N I_{t-1}}{N I_{t-1}}\right)_{i=1}- \\
\sum_{u=i}\left(\frac{\text { pay }_{t}-\text { pay }_{t-1}}{\text { pay }_{t-1}} / \frac{N I_{t}-N I_{t-1}}{N I_{t-1}}\right)_{i=0}
\end{gathered}
$$

Using listed company executive compensation and company performance data, calculate the performance sensitivity of executive compensation and its average value during the rolling five years of performance increase and performance decline, and subtract the average sensitivity value when performance rises from the average sensitivity when performance declines to get high manage salary stickiness. In the above formula: pay represents the total annual remuneration of the top three executives of the company; NI represents the performance of the company (measured by the net profit refers to the previous study), $i=1$, the performance rises, and $i=0$, the performance declines. First, use "( payt $_{t}-$ pay $\left._{\mathrm{t}-1}\right) /\left(\right.$ pay $\left._{\mathrm{t}-1}\right)$ " to calculate the rate of change in total executive compensation, and " $\left(\mathrm{NI}_{\mathrm{t}}-\mathrm{NI}_{\mathrm{t}-1}\right) /\left(\mathrm{NI}_{\mathrm{t}-1}\right)$ " to calculate the rate of change in performance; secondly, Use "(salary change rate/performance change rate)/performance change rate" to calculate the salary performance sensitivity; finally, use "(the average value of salary performance sensitivity when performance rises-the average value of salary performance sensitivity when performance declines) " to calculate the executive salary stickiness that this paper ultimately needs (if the performance growth during the 5year rolling period is continuously positive or negative, the sensitivity of salary performance when performance rises or falls will be missing, and salary stickiness cannot be calculated, so this sample is excluded).

Institutional investor shareholding ratio as a moderating variable uses the overall shareholding of institutional investors as a percentage of tradable A shares.

At the same time, enterprise size (SIZE), total assetliability ratio (LEV), enterprise growth (GROWTH), return on total assets (ROA), management expense ratio (ADM) are controlled. In addition, industry and annual effects were controlled. The variable definition is shown in Table 1.

\subsection{Model construction}

In order to test the relationship between the stickiness of executive compensation and enterprise innovation investment, the following regression model 1 is established:

$$
\begin{gathered}
R \& D_{i, t}=\beta_{0}+\beta_{1} N X_{i, t}+\beta_{2} S_{I Z E_{i, t}+}+\beta_{3} L E V_{i, t}+ \\
\beta_{4} G R O W T H_{i, t}+\beta_{5} A D M_{i, t}+\beta_{6} R O A_{i, t}+\sum I N D+ \\
\sum Y E A R+\varepsilon_{i, t}
\end{gathered}
$$

In order to test the regulatory effect of institutional investor shareholding on the relationship between executive salary stickiness and innovation investment, the

\begin{tabular}{|c|c|}
\hline symbols & Variable definition \\
\hline$R \& D_{i, t}$ & $\mathrm{R} \& \mathrm{D} /$ total asset \\
\hline$N X_{i, t}$ & Using the top three executive \\
\hline & $\begin{array}{l}\text { salaries, calculate the difference between } \\
\text { the average sensitivity of performance } \\
\text { increase and the average sensitivity of } \\
\text { performance decline during the rolling } \\
\text { five-year period }\end{array}$ \\
\hline$I N S_{i, t}$ & $\begin{array}{c}\text { Institutional investors' overall } \\
\text { holdings/tradable A shares }\end{array}$ \\
\hline$R O A_{i, t}$ & Net profit/total asset \\
\hline$A D M_{i, t}$ & Management costs/total asset \\
\hline GROWTH $_{i, t}$ & Growth rate of total asset \\
\hline$S I Z E_{i, t}$ & Ln (total asset) \\
\hline$L E V_{i, t}$ & Total liabilities/total asset \\
\hline$\sum Y E A R$ & Year dummy variable \\
\hline$\sum I N D$ & Industry dummy variable \\
\hline
\end{tabular}
following regression model 2 is established:

$$
\begin{gathered}
R \& D_{i, t}=\beta_{0}+\beta_{1} N X_{i, t}+\beta_{2} I N S_{i, t}+\beta_{3} N X_{i, t} * I N S_{i, t}+ \\
\beta_{4} S I Z E_{i, t}+\beta_{5} L E V_{i, t}+\beta_{6} G R O W T H_{i, t}+\beta_{7} A D M_{i, t}+ \\
\beta_{8} R O A_{i, t}+\sum I N D+\sum Y E A R+\varepsilon_{i, t}
\end{gathered}
$$

Table1 Variable definition 


\section{Empirical results and analysis}

\subsection{Descriptive statistics}

Table 2 is the result of descriptive statistics. On average, corporate innovation investment accounts for about $4.6 \%$ of the company's operating income (R\&D), reflecting the low level of corporate innovation investment in China. With a minimum of 0.00180 and a maximum of 76.35 , there is a huge gap in corporate innovation investment. The average value of executive salary stickiness (NX) is 3.758 , indicating that the increase in executive pay when performance increases is $3.758 \%$ higher than the decrease in executive pay when performance decreases by the same degree. When the value of salary stickiness is greater than 0 , it means that there are sticky characteristics in executive compensation. In the robustness test, this paper also removes samples with salary sticky values less than 0 . The result has no effect. The average shareholding ratio of institutional investors is 0.411 , which means that most of the company's institutional investors hold less than $50 \%$ of the shareholding ratio, but the minimum value is $1.00 \mathrm{e}-$ 06 and the maximum value is 0.911 . Therefore, among the samples, there is still a big difference in the shareholding ratio, and the two-level differentiation is serious.

Table 2 descriptive statistics

\begin{tabular}{lccccc}
\hline & $\mathrm{N}$ & mean & $\mathrm{sd}$ & $\mathrm{min}$ & $\max$ \\
\hline R\&D & 8,420 & 4.589 & 4.736 & 0.00180 & 76.35 \\
NX & 8,420 & 3.758 & 40.17 & -62.30 & 1,538 \\
INS & 8,420 & 0.411 & 0.249 & $1.00 \mathrm{e}-06$ & 0.911 \\
SIZE & 8,420 & 22.32 & 1.243 & 19.41 & 28.64 \\
LEV & 8,420 & 0.404 & 0.188 & 0.00836 & 2.579 \\
GROW & 8,420 & 0.388 & 6.984 & -0.982 & 429.0 \\
TH & & & & & \\
ADM & 8,420 & 0.0929 & 0.109 & 0.00128 & 7.284 \\
ROA & 8,420 & 0.0366 & 0.0844 & -3.911 & 0.526 \\
\hline
\end{tabular}

\subsection{The empirical results and analysis}

\begin{tabular}{|c|c|c|}
\hline \multicolumn{3}{|c|}{ Table 3 regression result } \\
\hline Variables & $R \& D_{i, t}$ & $R \& D_{i, t}$ \\
\hline$N X_{i, t}$ & $\begin{array}{c}0.002 * * * \\
(4.01)\end{array}$ & $\begin{array}{l}-0.000 \\
(-0.11)\end{array}$ \\
\hline$I N S_{i, t}$ & & $\begin{array}{c}-1.056 * * * \\
(-5.85)\end{array}$ \\
\hline$N X I N S_{i, t}$ & & $\begin{array}{c}0.001 * * \\
(2.36)\end{array}$ \\
\hline$S I Z E_{i, t}$ & $\begin{array}{c}-0.128 * * \\
(-2.31)\end{array}$ & $\begin{array}{c}-0.040 \\
(-0.69)\end{array}$ \\
\hline$L E V_{i, t}$ & $\begin{array}{c}-4.127 * * * \\
(-8.27)\end{array}$ & $\begin{array}{c}-4.100 * * * \\
(-8.27)\end{array}$ \\
\hline GROWTH $_{i, t}$ & $\begin{array}{c}0.011 * * * \\
(3.02)\end{array}$ & $\begin{array}{c}0.011 * * * \\
(3.06)\end{array}$ \\
\hline$A D M_{i, t}$ & $\begin{array}{c}18.003 * * * \\
(4.06)\end{array}$ & $\begin{array}{c}17.969 * * * \\
(4.06)\end{array}$ \\
\hline$R O A_{i, t}$ & $\begin{array}{c}-1.530 \\
(-1.46)\end{array}$ & $\begin{array}{l}-1.352 \\
(-1.26)\end{array}$ \\
\hline year & yes & yes \\
\hline industry & yes & yes \\
\hline Obs & 8420 & 8420 \\
\hline
\end{tabular}

\begin{tabular}{ccc}
\hline Cons & 4.342 & 2.773 \\
adjusted $\boldsymbol{R}^{\mathbf{2}}$ & 0.450 & 0.452 \\
\hline
\end{tabular}

Table 3 shows the regression results of Model 1 and Model 2. The regression coefficient of NX and R\&D in Model 1 is 0.002 , and it is significantly positive at the $1 \%$ level, indicating that the higher the stickiness of executive compensation, the higher the level of corporate innovation investment, and there is a positive correlation between the stickiness of executive compensation and corporate innovation investment relationship, the regression results support H1.

Model 2 adds the regulatory variable of institutional investor shareholding on the basis of model 1, and crosses the institutional investor shareholding with the stickiness of executive compensation to obtain the moderating effect on the relationship between the stickiness of executive compensation and corporate innovation investment. From the empirical results of Model 2, it can be found that the regression coefficient of the cross-multiplication term (NXINS) between the stickiness of executive compensation and institutional investor shares is 0.001 , and it is significantly positive at the $5 \%$ level. It can be seen that, as an important external governance mechanism, institutional investors generally play the role of "active shareholders" to strengthen the positive impact of executive compensation stickiness on corporate innovation investment, and the return results support $\mathrm{H} 2$.

\subsection{Further analysis}

This paper further distinguishes whether state-owned enterprises are analyzed. The results shows that the coefficient of executive salary stickiness (NX) is only positive in the sample of non-state-owned enterprises and is significant at the $1 \%$ level, and it is positive but not significant in the state-owned enterprises. For non-stateowned enterprises, the more tolerant of the failures of senior management, the more inclined to "tolerate early failures" and "heavy rewards and light penalties" in the compensation contract, which is more conducive to promoting the risk-taking of senior management and promoting senior management to improve the level of innovation input of enterprises. The reason for the difference may be that, compared with state-owned enterprises, private enterprises have more fierce market competition. They must increase investment in innovation and continuously introduce new products with lower cost and better quality to attract consumers, thereby maintaining their market position and market share.

\subsection{Robustness test}

In order to ensure the robustness of the empirical results, this paper adopts the following methods to test the robustness: (1) The stickiness of executive compensation is the company's consideration of failure tolerance, which makes compensation upward "flexible" and downward "rigid" However, when the salary stickiness is less than 0 , it means that there may be a greater tendency to "punish bad" in the company. Therefore, consider removing the 
observed value of executive salary stickiness less than 0 and re-regression. (2) Excluded other policies or major events that interfere with executive compensation and corporate innovation, this paper only retains the data for 2017-2019 to re-regress. The regression results show that the test results are still stable, and there is no substantial difference from the previous conclusions.

\section{Conclusion}

Innovation is the driving force of a country's economic growth and development, and it is also the key to a company's growth and improving market competitiveness. However, innovation is a long-term activity with high risk, which requires indefinite exploration and constant trial and error. Therefore, companies need to appropriately include the consideration of "tolerance of failure" when designing compensation contracts, so as to increase the willingness of senior management to take risks and promote corporate innovation. The research found in this paper: (1) The higher the stickiness of executive compensation, the higher the level of corporate innovation investment, and this relationship is more significant in non-state-owned enterprises. (2) After institutional investors intervene in corporate governance, they have exerted active governance. The effect has strengthened the positive correlation between the stickiness of executive compensation and corporate innovation investment.

\section{References}

1. MANSO G. Motivating innovation [J]. JF, 66, 18231860(2011).

2. Fang Junxiong. Is there stickiness in the salary of executives of listed companies in my country? [J]. ER, 44, 110-124(2009).

3. $\mathrm{Xu}$ Yue, Liu Yunguo, Cai Guilong. Executive Salary Stickiness and Enterprise Innovation [J]. AR, 7, 4349(2018).

4. EDERER F, MANSO G. Is pay for performance detrimentalto innovation? [J]. MS, 59, 1496-1513 (2013).

5. AGHION P, VAN REENEN J, ZINGALES L. Innovation and institutional ownership [J]. AER, 103, 277-304(2013).

6. Yi Yanxin, Qiu Kaili. Can "heavy rewards and light penalties" promote enterprise innovation?_-Based on the perspective of internal control and internal governance regulation [J]. NJAU, 17, 40-50(2020).

7. $\mathrm{Bu}$ Danlu, Wen Caihong. Does executive salary stickiness increase corporate investment? [J]. FR, 6, 63-72(2013). 